\title{
Experimental Investigation of the Effects of Partial Shading on Photovoltaic Cells' Electrical Parameters
}

\author{
W. B. Xiao, ${ }^{1,2}$ F. Y. Hu, ${ }^{1,2}$ H. M. Zhang, ${ }^{1,2}$ and H. M. Wu ${ }^{1,2}$ \\ ${ }^{1}$ Jiangxi Engineering Laboratory for Optoelectronics Testing Technology, Nanchang Hangkong University, Nanchang 330063, China \\ ${ }^{2}$ Key Lab of Non Destructive Test (Ministry of Education), Nanchang Hangkong University, Nanchang 330063, China
}

Correspondence should be addressed to W. B. Xiao; xiaowenbo1570@163.com

Received 5 September 2015; Revised 16 October 2015; Accepted 18 October 2015

Academic Editor: Clito Afonso

Copyright (C) 2015 W. B. Xiao et al. This is an open access article distributed under the Creative Commons Attribution License, which permits unrestricted use, distribution, and reproduction in any medium, provided the original work is properly cited.

The short-circuit current $\left(I_{\mathrm{sc}}\right)$, the open-circuit voltage $\left(V_{\mathrm{oc}}\right)$, and the maximum power point $\left(V_{\mathrm{MPP}}, I_{\mathrm{MPP}}\right)$ of monocrystalline and multicrystalline silicon solar cells under three kinds of partial shading patterns have been investigated experimentally. The partial shades are, respectively, the nine shelter locations by $1 \mathrm{~cm} \times 1 \mathrm{~cm}$ black card, the six shelter locations by $2 \mathrm{~cm} \times 1 \mathrm{~cm}$ black card, and the center shelters with isosceles triangle, circle, square, and two rectangles black cards whose areas are $2 \mathrm{~cm}^{2}$. Firstly, the results show that the partial shading causes disproportional high losses on those parameters of both cells but will have a minimal effect on $V_{\mathrm{oc}}$. Secondly, it is found that those parameters of the monocrystalline cell are less dependent on the shading than that of the multicrystalline cell. Thirdly, it is noted that $I_{\mathrm{sc}}$ and $I_{\mathrm{MPP}}$ of both cells will be decreasing dramatically as a rectangular black shading card with a long side parallel to cell's finger, compared with that normal to cell's finger. Finally, it can be seen that the effects of shading on the electrical parameters of both cells will be suppressed when the border lines of shading match the size of the shaded cell.

\section{Introduction}

Photovoltaic (PV) power is now becoming an important energy source. Not only is PV power environmentally friendly but also it has been becoming economically competitive with conventional fuels $[1,2]$. However, PV energy production is easily influenced by the shadow of natural and human made objects [3-5]. The shaded cells absorb electric power generated by the unshaded cells, causing hot spots that can irreversibly damage PV cells. Therefore, the output performances of PV cells under partial shading conditions have been drawing increasing attention [6-11]. Over the years, the theoretical researches are mainly based on the singlediode model [12-15] and the double-diode model [16-18]. However, it is obvious that those theoretical models do not always fit to complex and changeable shading environments. In addition, several researchers have adopted an experimental approach to study the characteristics of PV cells under partial shading conditions. The behaviors of the solar cell electrical parameters have been compared with the central and edge shading $[19,20]$. It was found that edge shading is a problem occurring in PV concentrator systems. The effects of shading percentage on electrical parameters of solar cells have been analyzed $[21,22]$. The results showed that the generated current is decreasing as the shading profile is increasing. However, none of the above researches clarifies the effects of shading shape on cell's performances. Furthermore, there are also lacks of detailed comparative studies of different kinds of solar cells under same shading condition. As a result, the nonlinear characteristics of electrical parameters of PV cells under partial shading still remain elusive.

In this paper, the electrical parameters (the short-circuit current $\left(I_{\mathrm{sc}}\right)$, the open-circuit voltage $\left(V_{\mathrm{oc}}\right)$, and the maximum power point $\left.\left(V_{\mathrm{MPP}}, I_{\mathrm{MPP}}\right)\right)$ of monocrystalline and multicrystalline silicon solar cells under three kinds of partial shading patterns have been investigated experimentally. The results firstly show that the partial shading causes disproportional high losses on electrical parameters of monocrystalline and multicrystalline cells. But the shading will have a minimal effect on the open-circuit voltage of both cells. Secondly, it is found that the electrical parameters of the monocrystalline cell are less dependent on the shading than those parameters 


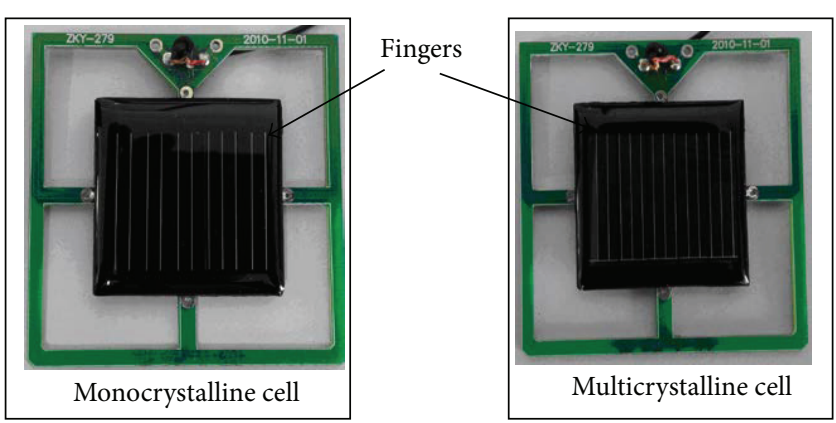

(a)

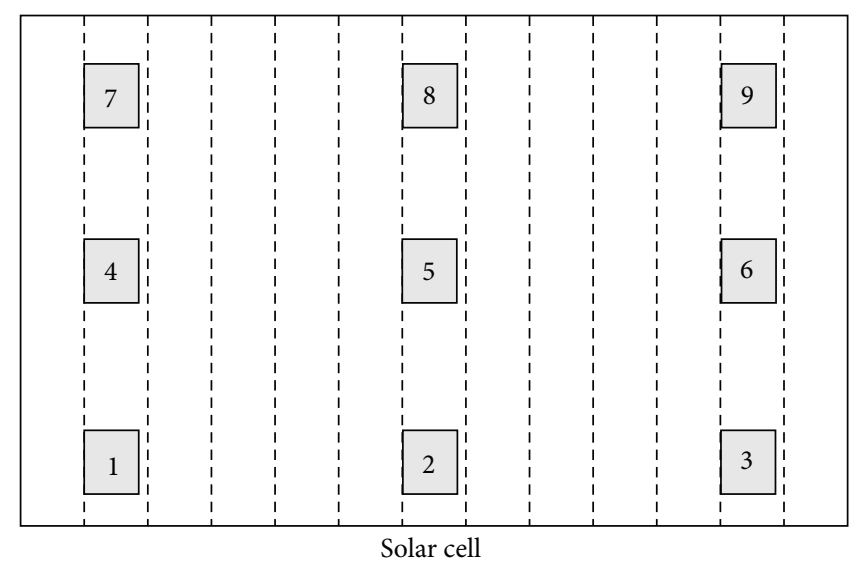

(b)
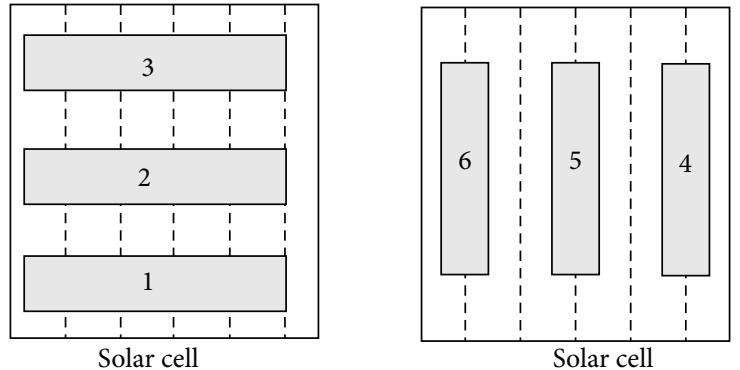

(c)
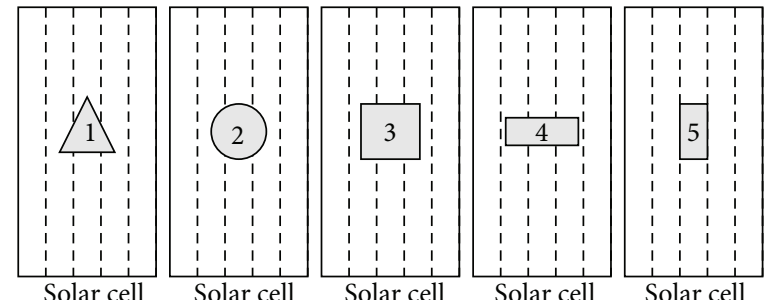

(d)

FIgURE 1: Experimental samples (a), the nine shelter locations by using $1 \mathrm{~cm} \times 1 \mathrm{~cm}$ black square card (b), the six shelter locations by using $2 \mathrm{~cm} \times 1 \mathrm{~cm}$ black rectangle card (c), and the center shelters with isosceles triangle, circle, square, and two rectangles black cards whose areas are $2 \mathrm{~cm}^{2}$ (d). The dashed lines are the cell's fingers (not to scale).

of multicrystalline cell. Thirdly, it is noted that the shortcircuit current and current at maximum power point of both cells will be decreasing dramatically as a rectangular black shading card with a long side parallel to cell's finger, compared with that normal to cell's finger. Finally, it can be seen that the effect of shading on the electrical parameters of both cells will be significantly suppressed when the border lines of shading match the shaded cell.

\section{Experimental Samples, Setup, and Shading Patterns}

The experimental samples are $2.8 \mathrm{~cm} \times 2.5 \mathrm{~cm}$ monocrystalline and multicrystalline silicon solar cells manufactured by QS Solar Company (Figure 1(a)). The distance between fingers of monocrystalline and multicrystalline cells is about $0.25 \mathrm{~cm}$. The $\mathrm{PV}$ testing system (number $\mathrm{SAC}-\mathrm{III}+\mathrm{G}$ 


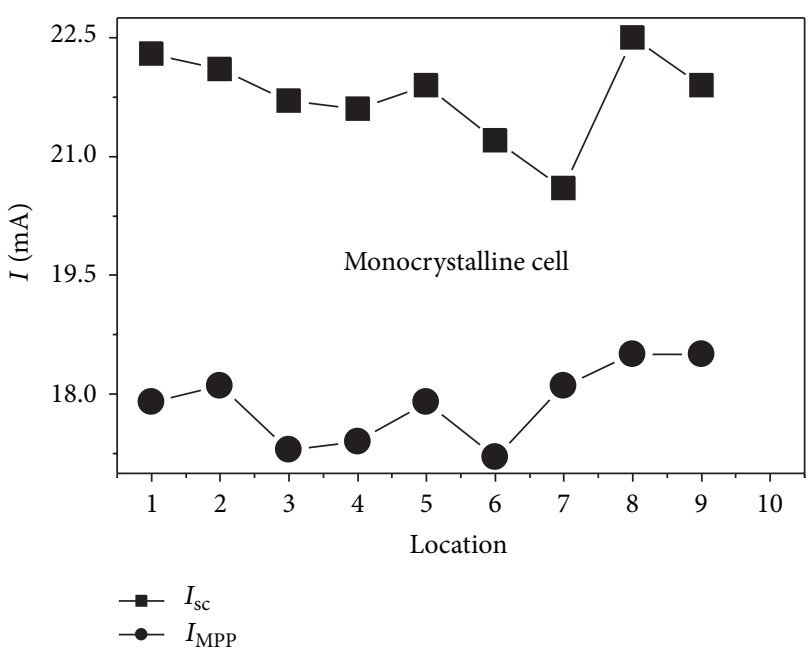

(a)

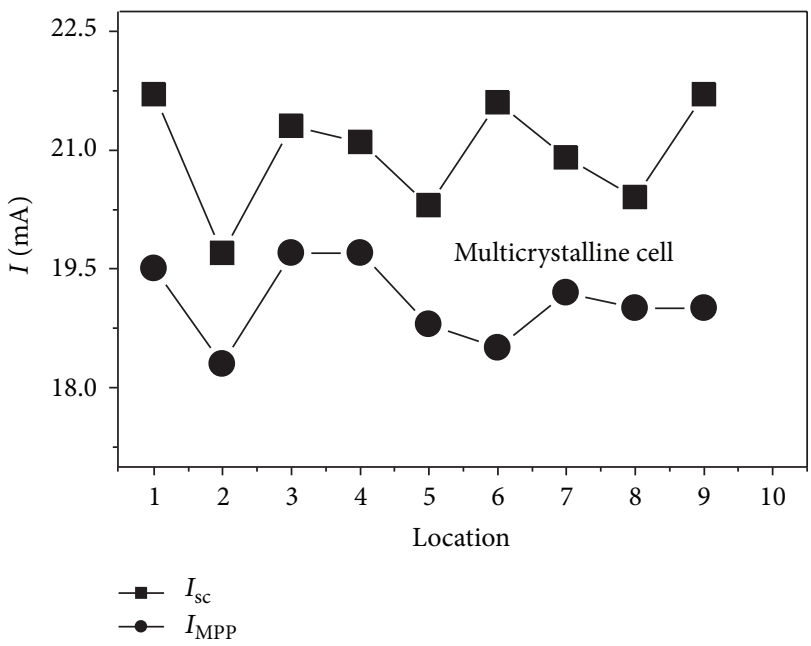

(c)

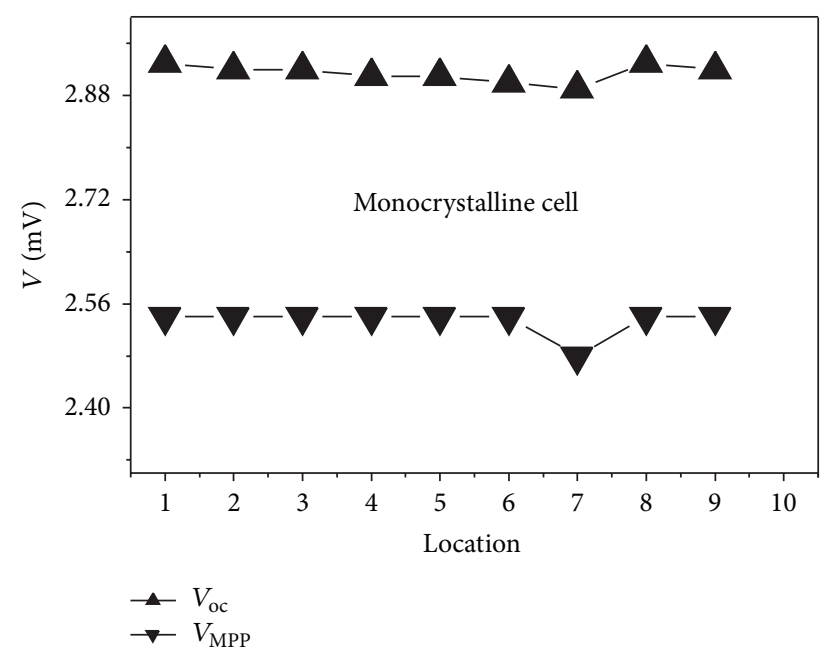

(b)

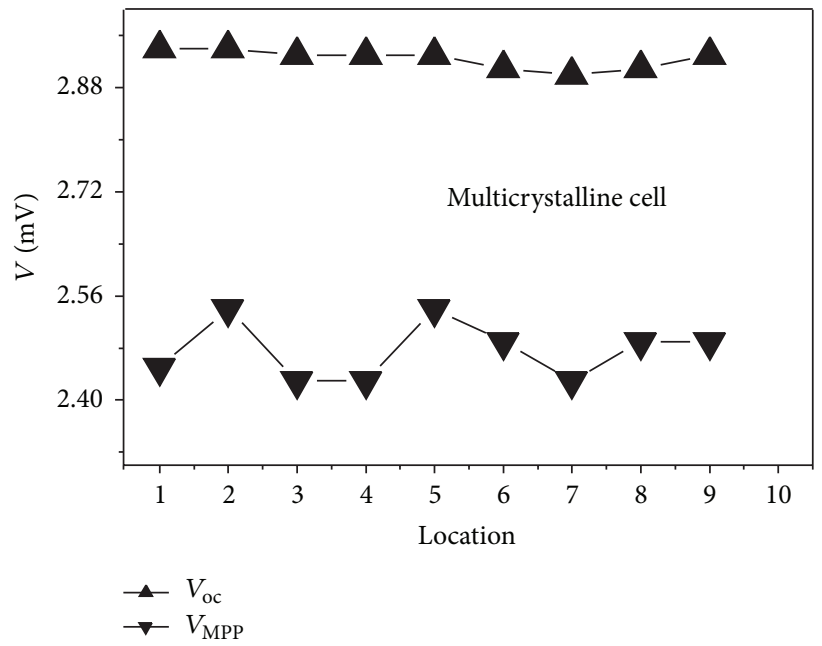

(d)

FIGURE 2: $I_{\mathrm{sc}}, I_{\mathrm{MPP}}, V_{\mathrm{oc}}$, and $V_{\mathrm{MPP}}$ of monocrystalline ((a) and (b)) and multicrystalline ((c) and (d)) silicon solar cells against nine square shelter locations.

made by Chengdu ZKY Instrument Co. Ltd.) is used for data acquisition. The testing system mainly includes a solar simulator, an electric signal reading device, and temperature control equipment, which are enclosed in a dark box. The simulated sunlight is achieved by Xenon light source. The beam impinges perpendicularly on the cell. The cell is placed in a temperature control room wherein temperature can be controlled by temperature control equipment, a semiconductor refrigeration device. The photoelectric signal of cell is recorded by the electric signal reading device. All the experiments were done at a temperature of $25^{\circ} \mathrm{C}$ and a light intensity of $1000 \mathrm{~W} / \mathrm{m}^{2}$. In the above condition, $I_{\mathrm{sc}}, V_{\mathrm{oc}}, I_{\mathrm{MPP}}$, and $V_{\text {MPP }}$ of unshaded monocrystalline (multicrystalline) cell are $30.5(30.1) \mathrm{mA}, 3.02(2.99) \mathrm{mV}, 27.6(29.3) \mathrm{mA}$, and 2.49 (2.48) $\mathrm{mV}$.

In order to study the effects of shading on solar cell's performances, three kinds of partial shading patterns are designed as shown in Figures 1(b), 1(c), and 1(d). Those configurations are not scaled in relation to cell dimensions, which purpose is to mark all the shading parts in a schematic diagram of a solar cell. The partial shades are, respectively, the nine shelter locations by $1 \mathrm{~cm} \times 1 \mathrm{~cm}$ black card, the six shelter locations by $2 \mathrm{~cm} \times 1 \mathrm{~cm}$ black card, and the center shelters with isosceles triangle, circle, square, and two rectangles black cards whose areas are $2 \mathrm{~cm}^{2}$. In the real experiment, the numbers of measurements are, respectively, nine for the square shelter configuration, six for the rectangle shelter configuration, and five for the center shelter configuration.

\section{Results and Discussion}

3.1. Nine Square Shelter Locations. In Figure $2, I_{\mathrm{sc}}, I_{\mathrm{MPP}}, V_{\mathrm{oc}}$, and $V_{\text {MPP }}$ of monocrystalline and multicrystalline cells are measured against nine square shelter locations. Firstly, it can be seen that $I_{\mathrm{sc}}, I_{\mathrm{MPP}}, V_{\mathrm{oc}}$, and $V_{\mathrm{MPP}}$ of both cells are obviously less than those of the unshaded cells. The reason is that the 


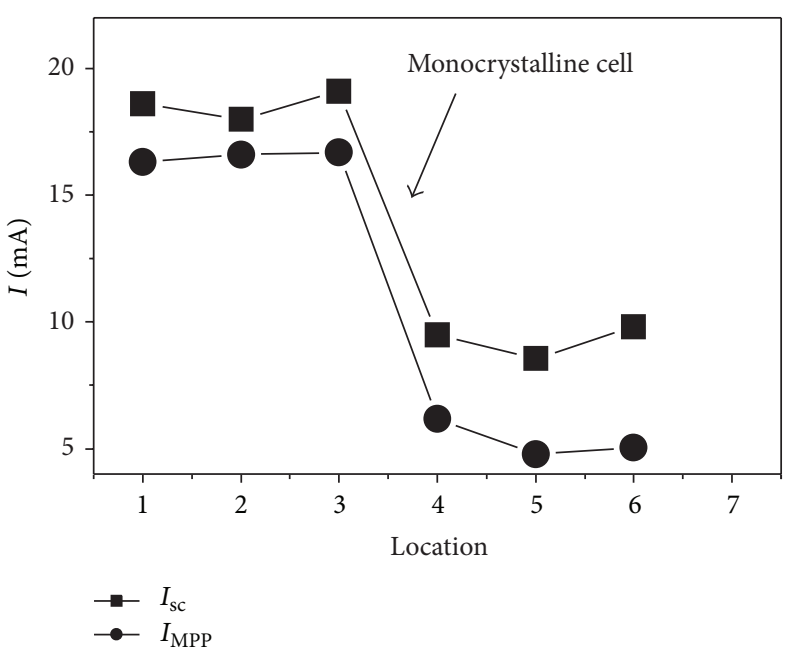

(a)

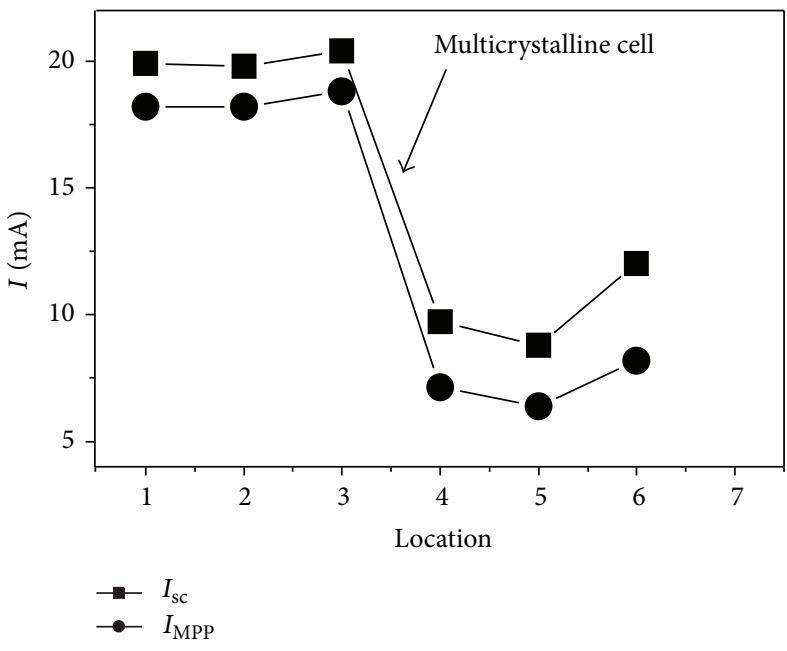

(c)

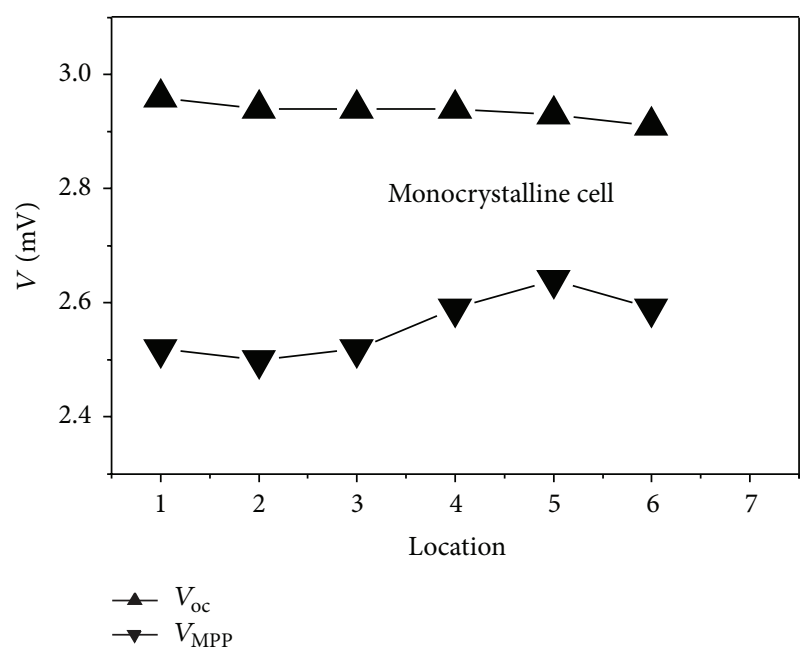

(b)

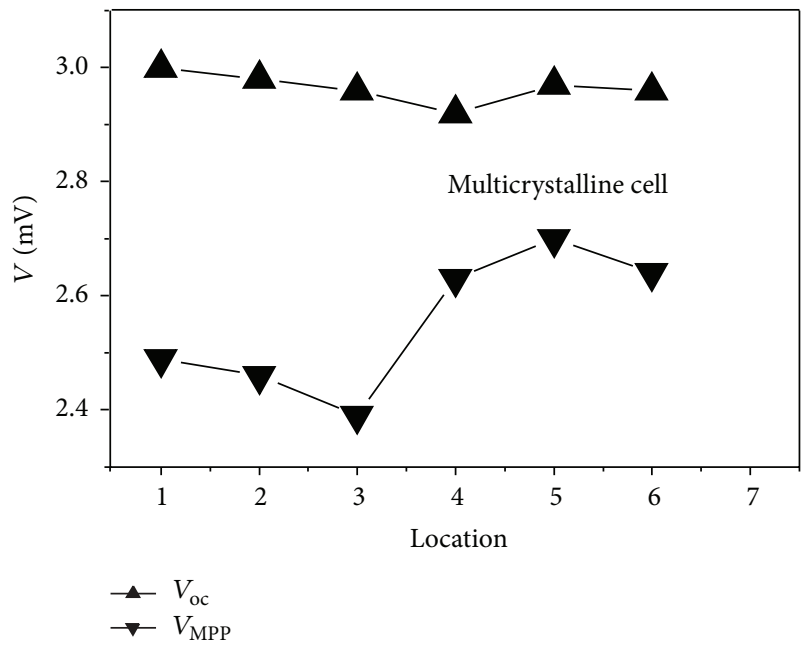

(d)

FIGURE 3: $I_{\mathrm{sc}}, I_{\mathrm{MPP}}, V_{\mathrm{oc}}$, and $V_{\mathrm{MPP}}$ of monocrystalline ((a) and (b)) and multicrystalline ((c) and (d)) silicon solar cells against six rectangle shelter locations.

light-receiving area of the cell is reduced. The average $I_{\mathrm{sc}}$ of monocrystalline and multicrystalline cells under nine square shelter locations are about $21.75556 \mathrm{~mA}$ and $20.96667 \mathrm{~mA}$. In fact, PV cell can be divided into a number of subcells by the cell's fingers. In other words, cell can be regarded as subcells in series. The $I_{\mathrm{sc}}$ of unshaded monocrystalline and multicrystalline cells are $30.5 \mathrm{~mA}$ and $30.1 \mathrm{~mA}$. Namely, the $I_{\mathrm{sc}}$ of each subcell of monocrystalline and multicrystalline cells are about $30.5 \mathrm{~mA}$ and $30.1 \mathrm{~mA}$. When the cell is sheltered by using $1 \mathrm{~cm} \times 1 \mathrm{~cm}$ black square card, the light-receiving area of each sub-cell is $0.45 \mathrm{~cm}^{2}$ but not $0.7 \mathrm{~cm}^{2}$. According to previous research work [21,22], it is known that the $I_{\mathrm{sc}}$ are approximately proportional to the light-receiving area. As a result, the short-circuit current under shaded condition should be equal to $19.6 \mathrm{~mA}$ and $19.3 \mathrm{~mA}$ for the monocrystalline and multicrystalline cells, which are very close to the above experimental results. Therefore, the above conclusion is correct. Secondly, it is observed that those parameters vary with the shading positions. It is due to the fact that the devices themselves owned uniform defects [23]. Thirdly, it is noted that the standard deviations of $I_{\mathrm{sc}}, I_{\mathrm{MPP}}, V_{\mathrm{oc}}$, and $V_{\mathrm{MPP}}$ of monocrystalline (multicrystalline) cell are, respectively, 0.579032 (0.705337) mA, 0.486769 (0.499444) mA, 0.013333 $(0.01424) \mathrm{mV}$, and $0.02(0.044441) \mathrm{mV}$. Those show that shading locations have a minimal effect on $V_{o c}$, which also can be seen in Figure 2. The reason is that $V_{\text {oc }}$ is mainly determined by the band gap of the solar cell material, the device temperature, and the incident light intensity [24, 25]. In addition, it is found that the shading has more influence on the electrical parameters of the monocrystalline cell than that of the multicrystalline cell from the standard deviation. The differences can be regarded as the multicrystalline cell has much more nonuniformity defects.

3.2. Six Rectangle Shelter Locations. In Figure $3, I_{\mathrm{sc}}, I_{\mathrm{MPP}}$, $V_{\mathrm{oc}}$, and $V_{\mathrm{MPP}}$ of monocrystalline and multicrystalline cells 


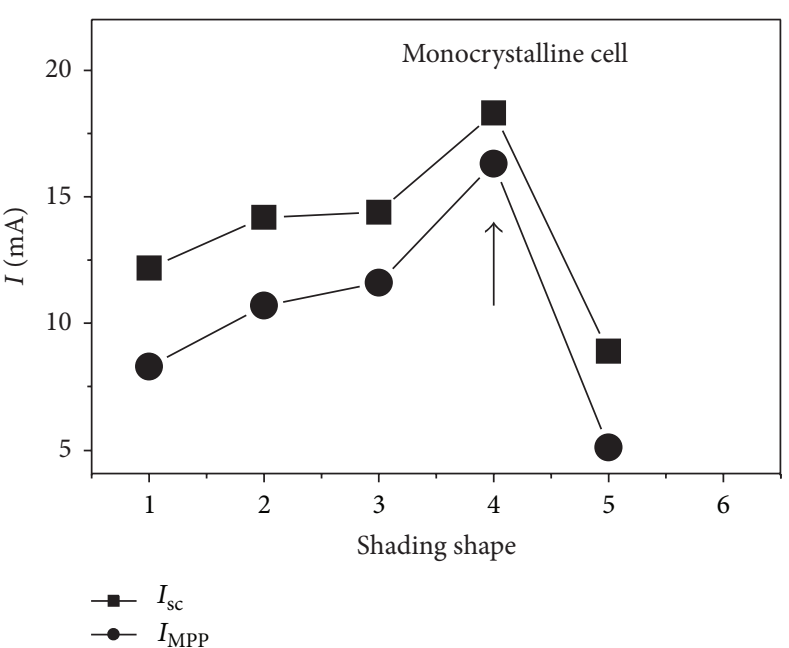

(a)

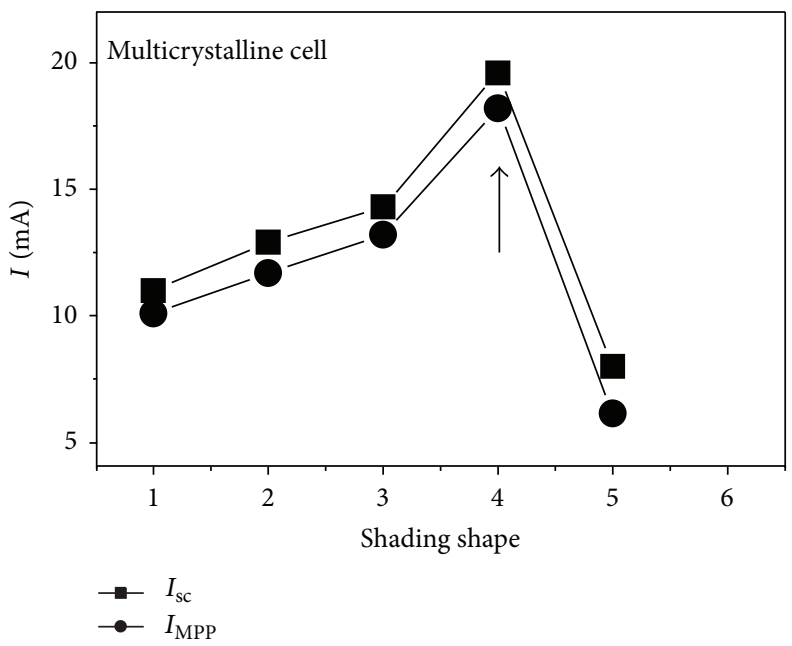

(c)

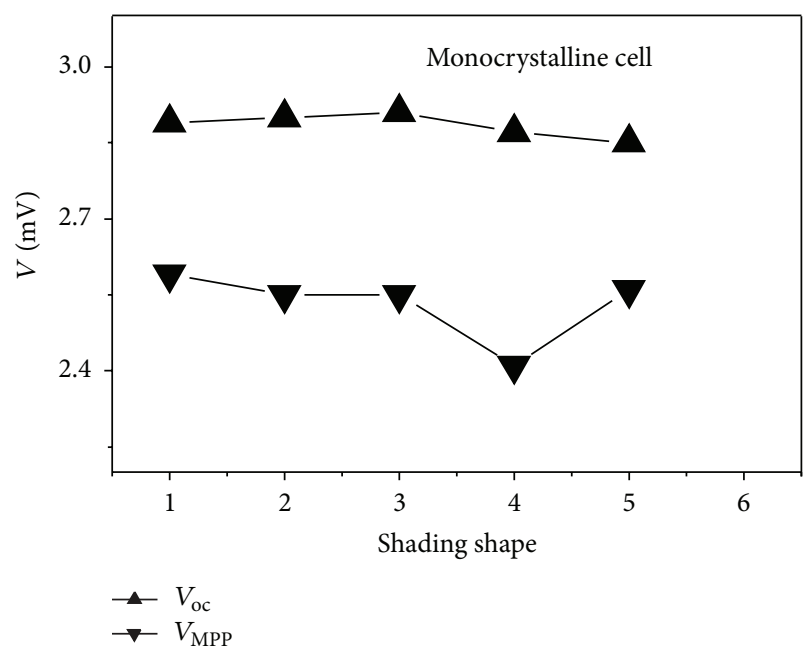

(b)

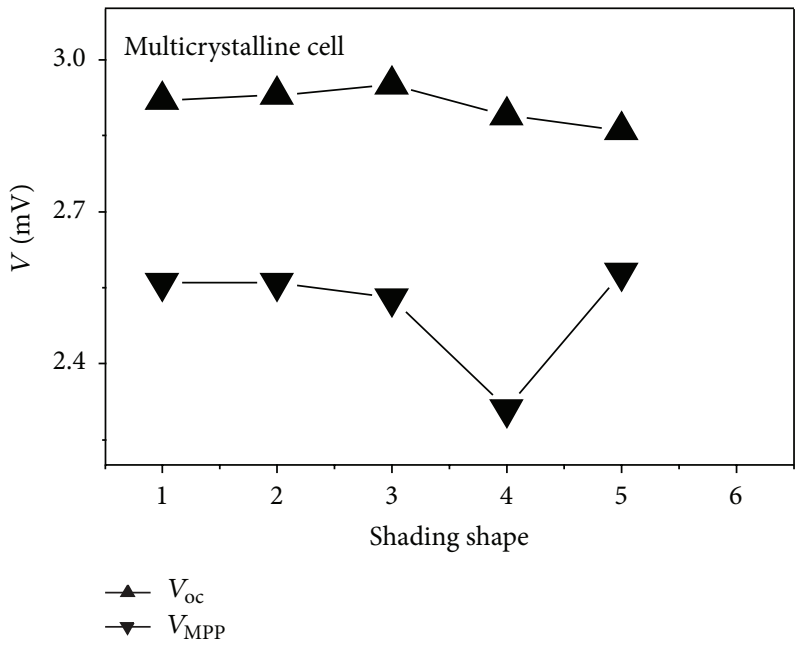

(d)

FIGURE 4: $I_{\mathrm{sc}}, I_{\mathrm{MPP}}, V_{\mathrm{oc}}$, and $V_{\mathrm{MPP}}$ of monocrystalline ((a) and (b)) and multicrystalline ((c) and (d)) silicon solar cells against center shelters with isosceles triangle, circle, square, and two rectangles black cards.

are measured against six rectangle shelter locations. It can also be seen that $I_{\mathrm{sc}}, I_{\mathrm{MPP}}, V_{\mathrm{oc}}$, and $V_{\mathrm{MPP}}$ of both cells are changing with the shading positions. The standard deviations of $I_{\mathrm{sc}}, I_{\mathrm{MPP}}, V_{\mathrm{oc}}$, and $V_{\mathrm{MPP}}$ of monocrystalline (multicrystalline) cell are, respectively, $5.105865(5.505853) \mathrm{mA}$, 6.1555 (6.146448) mA, $0.01633(0.026646) \mathrm{mV}$, and 0.054772 $(0.121888) \mathrm{mV}$, which also show that the shading has a minimal effect on $V_{\text {oc }}$ for both cells and on electrical parameters of monocrystalline cell. Those experimental results give a direct proof verifying the above conclusions. What should be noticed is that there are mutation process of $I_{\mathrm{sc}}$ and $I_{\text {MPP }}$ for both cells between the third and fourth locations as arrows shown in the Figures 3(a) and 3(c). This may be the differences between the long side of rectangular shading card normal to cell's finger and the long side of rectangular shading card parallel to cell's finger. When PV cell is covered by a black rectangular shading card with a long side normal to cell's finger, only $1 \mathrm{~cm}$ length is sheltered along the longitudinal direction for each subcell. The results of this shading mode are similar to the above case. So the short-circuit current under shaded condition should be equal to $19.6 \mathrm{~mA}$ and $19.3 \mathrm{~mA}$ for the monocrystalline and multicrystalline cells, which are also very close to the above experimental data. When PV cell is covered by a black rectangular shading card with a long side parallel to cell's finger, the $2 \mathrm{~cm}$ length is sheltered along the longitudinal direction for each subcell. Therefore, the short-circuit current under shaded condition should be equal to $8.7 \mathrm{~mA}$ and $8.6 \mathrm{~mA}$ for the monocrystalline and multicrystalline cells, which are also roughly consistent with experimental observation. As a result, the short-circuit current of cell is determined by the weakest subcell when the cell is partially shaded.

3.3. Center Shelters with Different Shapes. In Figure $4, I_{\mathrm{sc}}$, $I_{\mathrm{MPP}}, V_{\mathrm{oc}}$, and $V_{\mathrm{MPP}}$ of monocrystalline ((a) and (b)) and multicrystalline ((c) and (d)) silicon solar cells are measured 
against isosceles triangle, circle, square, and two rectangles black cards whose areas are $2 \mathrm{~cm}^{2}$. As it can be seen, the impacts of shading shapes on the electrical parameters of both cells are different. The standard deviations of $I_{\mathrm{sc}}$, $I_{\mathrm{MPP}}, V_{\mathrm{oc}}$, and $V_{\mathrm{MPP}}$ of monocrystalline (multicrystalline) cell are, respectively, 3.432929 (4.304997) $\mathrm{mA}, 4.145301$ (4.411136) $\mathrm{mA}, \quad 0.024083 \quad(0.035355) \mathrm{mV}$, and 0.070143 (0.112116) $\mathrm{mV}$. The above conclusion can also be drawn from those results. It is particularly noticed that $I_{\mathrm{sc}}$ and $I_{\mathrm{MPP}}$ of both cells under square shading are maximum values for isosceles triangle, circle, and square shading, as shown in Figures 4(a) and 4(c). This can be explained by the fact that the border lines of square shading match the shaded cell's size. In addition, it is found that $I_{\mathrm{sc}}$ and $I_{\mathrm{MPP}}$ of both cells under a rectangular shading card with a long side parallel to cell's finger are minimum values. It is because of the combined effect of the above two factors. One factor is that a greater portion of each subcell is shaded in the above condition. Another is that the border lines of rectangle shading do not match the shaded cell's size. Therefore, $I_{\mathrm{sc}}$ and $I_{\mathrm{MPP}}$ of both cells under rectangles black card with a long side normal to cell's finger present a peak, as arrows shown in Figures 4(a) and 4(c).

\section{Conclusion}

In order to explain clearly the shading effects on the solar cell's performances, experiments under three kinds of partial shading patterns were carried out. Firstly, the results show that the partial shading causes disproportional high losses on electrical parameters of monocrystalline and multicrystalline cells but will have a minimal effect on $V_{\text {oc }}$ for both cells. The reason is that $V_{\mathrm{oc}}$ is mainly determined by the band gap of the solar cell material, the device temperature, and the incident light intensity. Secondly, it is found that electrical parameters of the monocrystalline cell are less dependent on the shading than that of multicrystalline cell. The differences can be regarded as the multicrystalline cell has much more nonuniformity defects. Thirdly, it is noted that the $I_{\mathrm{sc}}$ and $I_{\text {MPP }}$ of both cells will be decreasing dramatically as a rectangular black shading card with a long side parallel to cell's finger, compared with that normal to cell's finger. The reason of this behavior is due to the subcell in series being much more sheltered while card's long side parallel to cell's finger. Finally, it can be seen that the effects of shading on the electrical parameters of both cells will be suppressed when the border lines of shading match the size of the shaded cell.

\section{Conflict of Interests}

The authors declare that there is no conflict of interests regarding the publication of this paper.

\section{Acknowledgments}

This work was in part supported by National Natural Science Foundation of China under Grants nos. 11264031 and 11304145, Jiangxi Province Science Major Program for
Youths under Grant no. 20143ACB21011, and the Invention Patent Foundation of Jiangxi province under Grant no. 20143BBM26116.

\section{References}

[1] B. Sinha, "Trends in global solar photovoltaic research: silicon versus non-silicon materials," Current Science, vol. 100, no. 5, pp. 654-660, 2011.

[2] J.-T. Liu, X.-H. Deng, W. Yang, and J. Li, "Perfect light trapping in nanoscale thickness semiconductor films with a resonant back reflector and spectrum-splitting structures," Physical Chemistry Chemical Physics, vol. 17, no. 5, pp. 33033308, 2015.

[3] B. Parida, S. Iniyan, and R. Goic, "A review of solar photovoltaic technologies," Renewable and Sustainable Energy Reviews, vol. 15, no. 3, pp. 1625-1636, 2011.

[4] G. Makrides, B. Zinsser, M. Schubert, and G. E. Georghiou, "Energy yield prediction errors and uncertainties of different photovoltaic models," Progress in Photovoltaics: Research and Applications, vol. 21, no. 4, pp. 500-516, 2013.

[5] F. Lu, S. Y. Guo, T. M. Walsh, and A. G. Aberle, "Improved PV module performance under partial shading conditions," Energy Procedia, vol. 33, pp. 248-255, 2013.

[6] D. La Manna, V. Li Vigni, E. R. Sanseverino, V. Di Dio, and P. Romano, "Reconfigurable electrical interconnection strategies for photovoltaic arrays: a review," Renewable and Sustainable Energy Reviews, vol. 33, pp. 412-426, 2014.

[7] C. R. Sánchez Reinoso, D. H. Milone, and R. H. Buitrago, "Simulation of photovoltaic centrals with dynamic shading," Applied Energy, vol. 103, pp. 278-289, 2013.

[8] C. R. S. Reinoso, D. H. Milone, and R. H. Buitrago, "Efficiency study of different photovoltaic plant connection schemes under dynamic shading," International Journal of Hydrogen Energy, vol. 35, no. 11, pp. 5838-5843, 2010.

[9] H. Patel and V. Agarwal, "MATLAB-based modeling to study the effects of partial shading on PV array characteristics," IEEE Transactions on Energy Conversion, vol. 23, no. 1, pp. 302-310, 2008.

[10] M. C. Alonso-García, J. M. Ruiz, and F. Chenlo, "Experimental study of mismatch and shading effects in the I-V characteristic of a photovoltaic module," Solar Energy Materials and Solar Cells, vol. 90, no. 3, pp. 329-340, 2006.

[11] Y. Sun, S. Chen, L. Xie, R. Hong, and H. Shen, "Investigating the impact of shading effect on the characteristics of a largescale grid-connected PV power plant in northwest china," International Journal of Photoenergy, vol. 2014, Article ID 763106, 9 pages, 2014.

[12] T. Ma, H. X. Yang, and L. Lu, "Development of a model to simulate the performance characteristics of crystalline silicon photovoltaic modules/strings/arrays," Solar Energy, vol. 100, pp. 31-41, 2014.

[13] Y.-J. Wang and P.-C. Hsu, "An investigation on partial shading of PV modules with different connection configurations of PV cells," Energy, vol. 36, no. 5, pp. 3069-3078, 2011.

[14] M. Seyedmahmoudian, S. Mekhilef, R. Rahmani, R. Yusof, and E. T. Renani, "Analytical modeling of partially shaded photovoltaic systems," Energies, vol. 6, no. 1, pp. 128-144, 2013.

[15] J. B. Bai, Y. Cao, Y. Z. Hao, Z. Zhang, S. Liu, and F. Cao, "Characteristic output of PV systems under partial shading or mismatch conditions," Solar Energy, vol. 112, pp. 41-54, 2015. 
[16] S. Silvestre, A. Boronat, and A. Chouder, "Study of bypass diodes configuration on PV modules," Applied Energy, vol. 86, no. 9, pp. 1632-1640, 2009.

[17] K. Ishaque, Z. Salam, and Syafaruddin, "A comprehensive MATLAB Simulink PV system simulator with partial shading capability based on two-diode model," Solar Energy, vol. 85, no. 9, pp. 2217-2227, 2011.

[18] K. Ishaque, Z. Salam, H. Taheri, and Syafaruddin, "Modeling and simulation of photovoltaic (PV) system during partial shading based on a two-diode model," Simulation Modelling Practice and Theory, vol. 19, no. 7, pp. 1613-1626, 2011.

[19] A. E. Ghitas and M. Sabry, "A study of the effect of shadowing location and area on the Si solar cell electrical parameters," Vacuum, vol. 81, no. 4, pp. 475-478, 2006.

[20] M. Sabry and A. E. Ghitas, "Effect of edge shading on the performance of silicon solar cell," Vacuum, vol. 80, no. 5, pp. 444-450, 2006.

[21] V. Quaschning and R. Hanitsch, "Influence of shading on electrical parameters of solar cells," in Proceedings of the 25th IEEE Photovoltaic Specialists Conference, pp. 1287-1290, Washington, DC, USA, May 1996.

[22] A. Dolara, G. C. Lazaroiu, S. Leva, and G. Manzolini, "Experimental investigation of partial shading scenarios on PV (photovoltaic) modules," Energy, vol. 55, pp. 466-475, 2013.

[23] Z. T. Zhai, The output characteristic predicting of $P V$ array in arbitrary condition [Ph.D. thesis], University of Science and Technology of China, Hefei, China, 2008.

[24] K. Ding, J. W. Zhang, X. G. Bian, and J. W. Xu, "Simplified model for photovoltaic modules based on improved translation equations," Solar Energy, vol. 101, pp. 40-52, 2014.

[25] A. N. Celik and N. Acikgoz, "Modelling and experimental verification of the operating current of mono-crystalline photovoltaic modules using four- and five-parameter models," Applied Energy, vol. 84, no. 1, pp. 1-15, 2007. 

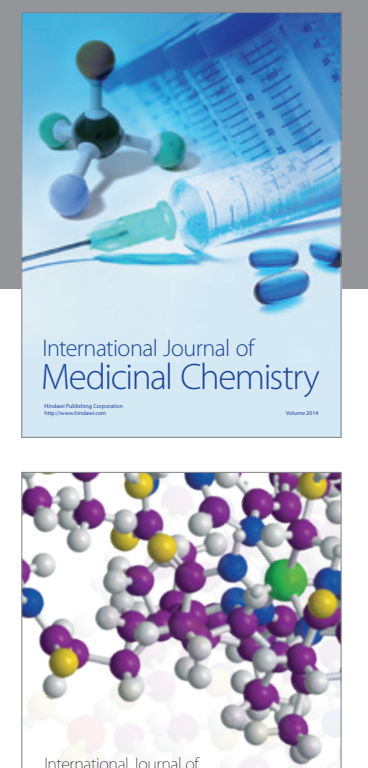

\section{Carbohydrate} Chemistry

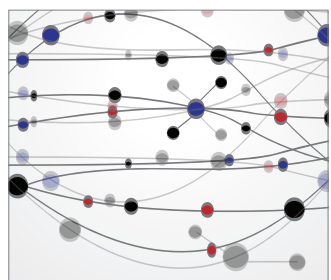

The Scientific World Journal
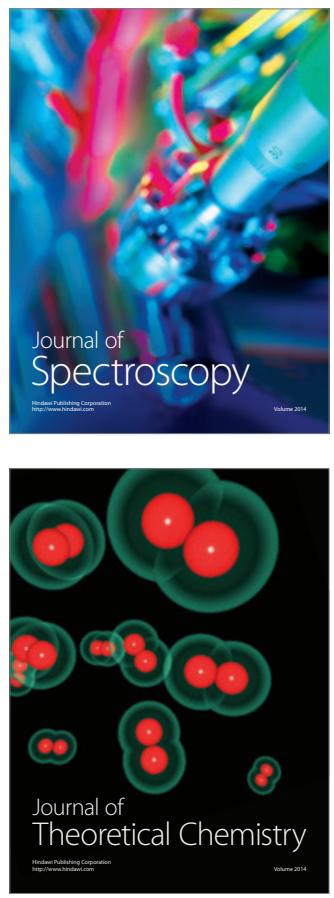
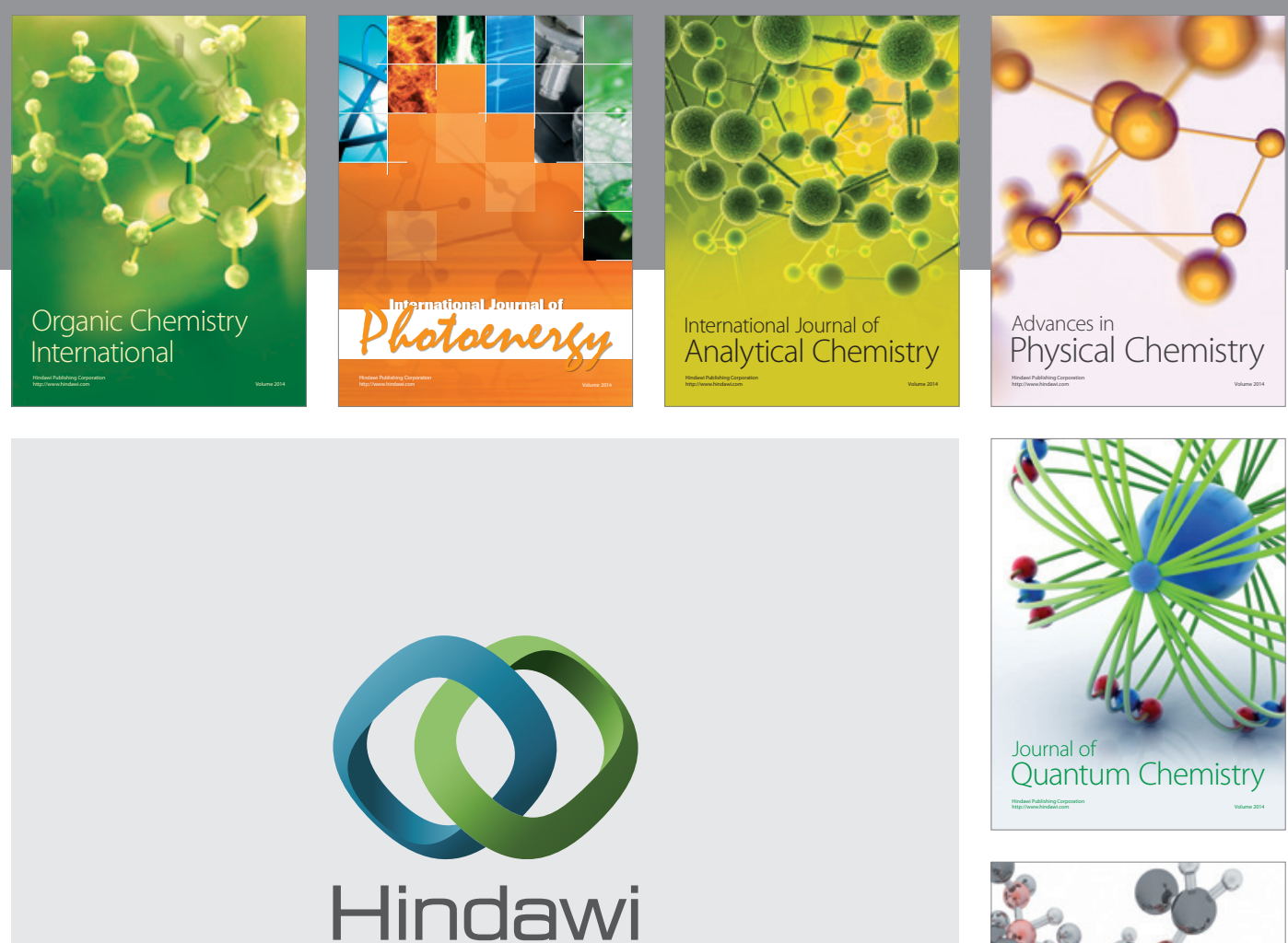

Submit your manuscripts at

http://www.hindawi.com

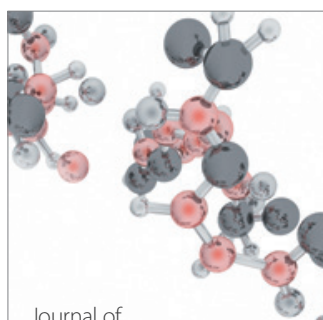

Analytical Methods

in Chemistry

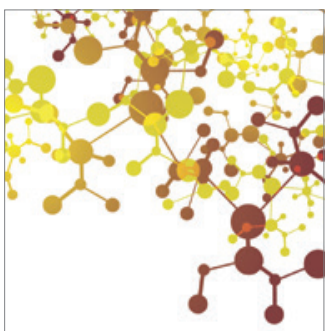

Journal of

Applied Chemistry

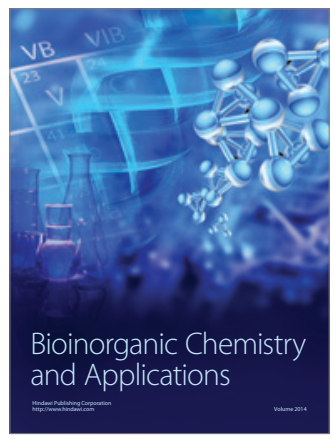

Inorganic Chemistry
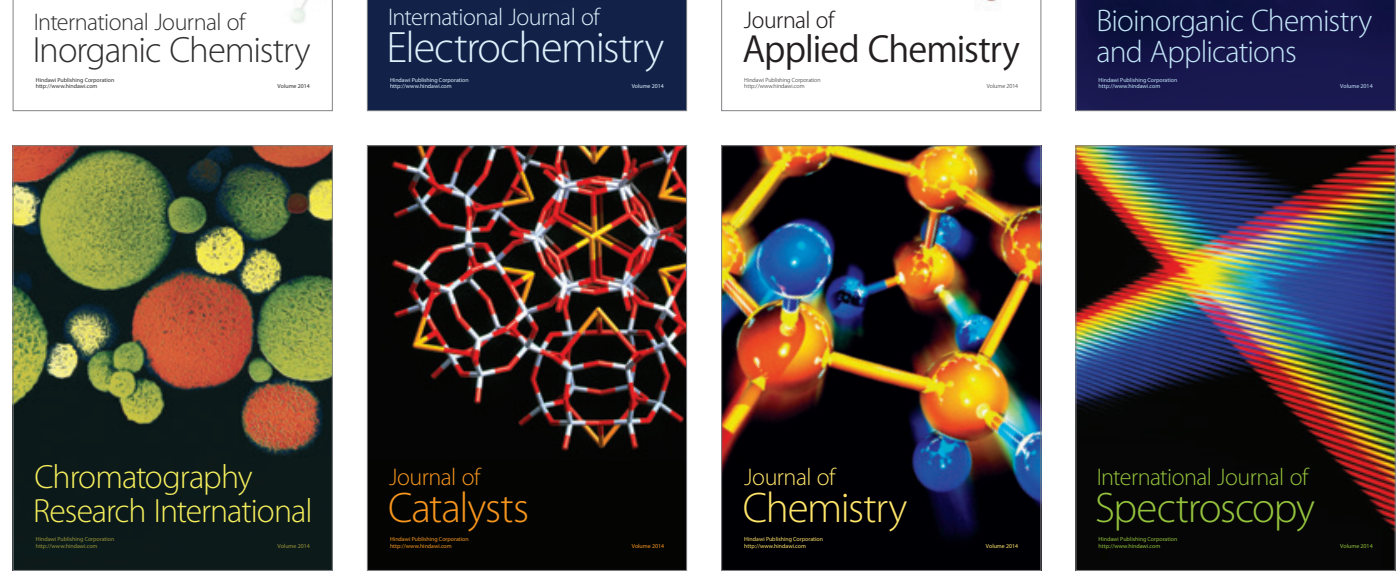